\title{
The COVID-19 Pandemic: Are There Any Impacts on Sustainability?
}

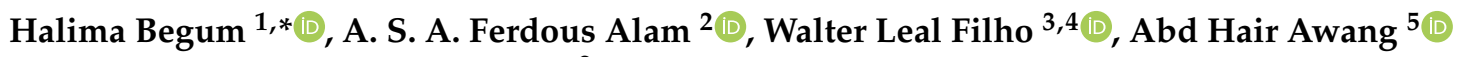 \\ and Ahmad Bashawir Abdul Ghani ${ }^{2}$
}

1 School of Economics, Finance, and Banking, Universiti Utara Malaysia UUM, Sintok 06010, Malaysia

2 School of International Studies, Universiti Utara Malaysia UUM, Sintok 06010, Malaysia; ferdous@uum.edu.my (A.S.A.F.A.); bashawir@uum.edu.my (A.B.A.G.)

3 Research and Transfer Centre "Sustainable Development and Climate Change Management", Hamburg University of Applied Sciences, Ulmenliet 20, 21033 Hamburg, Germany; walter.leal2@haw-hamburg.de

4 Department of Natural Sciences, Manchester Metropolitan University, Chester Street Manchester, Manchester M1 5GD, UK

5 Faculty of Social Sciences \& Humanities, Universiti Kebangsaan Malaysia UKM, Bangi 43600, Malaysia; hair@ukm.edu.my

* Correspondence: dr.halima.begum@uum.edu.my; Tel.: +604-928-6866

check for updates

Citation: Begum, H.; Alam, A.S.A.F.; Leal Filho, W.; Awang, A.H.; Ghani, A.B.A. The COVID-19 Pandemic: Are There Any Impacts on Sustainability? Sustainability 2021, 13, 11956. https://doi.org/10.3390/ su132111956

Academic Editor: Donato Morea

Received: 28 September 2021

Accepted: 16 October 2021

Published: 29 October 2021

Publisher's Note: MDPI stays neutral with regard to jurisdictional claims in published maps and institutional affiliations.

Copyright: (c) 2021 by the authors. Licensee MDPI, Basel, Switzerland. This article is an open access article distributed under the terms and conditions of the Creative Commons Attribution (CC BY) license (https:/ / creativecommons.org/licenses/by/ $4.0 /)$.

\begin{abstract}
This paper sets out to explain and describe the potential ways to control COVID-19's impact on the environment and what controllable strategies and anticipations emerge from rethinking sustainable production. The rapid and devastating spread of this disease has made millions of people throughout the world cover themselves, wear gloves, and use hand sanitizers and other medical applications. However, it means that a huge amount of clinical waste is being dumped into landfills or the oceans, and such activity may simply worsen the infection's transmission and the sustainability of the environment, the socio-economy, and sustainable productions. This disease has greatly changed the way people live and has caused considerable occupational job losses and misfortunes, sending sustainable businesses and other organizations to the wall. Virtually every country is trying to stop the infection transmission by testing patients and isolating people, but the environmental effects of the pandemic and sustainable business have not previously been analyzed. The study suggests that the current options for sustainable production must be measured and also further researched.
\end{abstract}

Keywords: coronavirus; COVID-19; SARS; worldwide health; sustainability; environment; socioeconomic; sustainable production

\section{Introduction}

In late December 2019, an unusual virus emerged in the Chinese city of Wuhan, and it was given the name COVID-19 a few months later [1,2]. Many medical clinics discovered a link between an animal or animals that spread to people and an abnormal lung-based ailment that occurred in people. Through critically required lab testing, the World Health Organization (WHO) began to formulate policies and strategies for treatment and immunization [3]. According to [4], a website produced by Johns Hopkins University, and other organizations [5], the World Health Organization observed that instances were increasing at worrisome rates in rural areas of China by 30 January 2020 [6], and that they were expanding globally. Up to mid-February 2020, when the sickness had not yet spread to other Asian countries, Europe, or North America, China had the highest mortality rate [7]. Coronaviruses are single-stranded RNA infections that can affect both humans and animals [8]. The authors of [9] found the illnesses and gave them the name Coronavirus, which is derived from the Latin term Corona, which refers to the crown garland [10]. Coronavirus has four distinct subfamilies. The beta-Coronavirus has also evolved as a virus capable of causing major disease, contamination, and death [11]. 
SARS-CoV- 2 is a beta-Coronavirus that causes $96 \%$ of infections [12,13]. SARS-CoV2-infected animals were sold in China's Wuhan market, and the clinical symptoms of the COVID-19 disease were closely related to SARS-CoV-2, allowing for the identification of cases of pneumonia with gastrointestinal symptoms and asymptomatic contaminations, particularly among children, with incubation periods ranging from 0 to 24 days $[7,11,14]$. The epidemic then spread to 200 countries and regions, infecting around 6,309,107 people and killing over 376,445 [6]. Subsequently, the COVID-19 pandemic has resulted in millions of affected people, complicated morbidities, and costs in the billions of dollars [15,16]. However, unlike other sicknesses and their outcomes, COVID-19 is likely to continue well into the future, as a vaccine has been discovered, like for other infectious ailments, but the infection rate is yet to worsen worldwide [7] and create unsustainability in the environment, economy, and social-wellbeing [17].

Nonetheless, whether environmental, socioeconomic, and sustainable production will be impacted by the COVID-19 pandemic is still being debated and is considered to be substantial [18]. The COVID-19 pandemic triggered an extraordinary calamity in such a short time, wreaking havoc on sustainable development and adversely affecting the world's poor and vulnerable [19]. Due to the pandemic, there are worldwide ecological consequences of COVID-19 proliferation [20], including climate change, soil degradation, ozone depletion, pollution, and urbanization, all of which worsen human and community health risks [21]. The global temperature increase was caused by technological advancements and the combustion of fossil fuels, which resulted in enormous $\mathrm{CO}_{2}$ emissions into the atmosphere for well over a century. However, [17] identified that the COVID-19 outbreak has the potential to significantly impact environmental sustainability through reduced material consumption for energy modification, resilience, and enhanced air quality.

Alongside this context, there are enormous challenges and maladies related to the need for extra protective measures to build a sustainable environment with economic emancipation and socio-economic development [17]. The COVID-19 pandemic has a detrimental impact on economic activity, human lives, and socioeconomic costs [22], as [23] assessed a trade-off between the severity of the epidemic's short-term recession, such as bankruptcy costs, unemployment hysteresis, and supply chain destruction, and the health repercussions. Due to the high unemployment rate in private employment, roughly 40-60 million people fall into extreme poverty as a result of COVID-19's escalating socioeconomic shocks around the world [18]. More surprisingly, energy and water consumption per service unit have increased in households due to the closing of schools, colleges, offices, restaurants, etc. [24]. Thus, there is a detrimental effect on the world economy, especially due to the decline of oil prices in organizations and petroleum exporting countries (OPECs); the travel, hotel, and tourism industry; the manufacturing industry, etc. [25]. Besides, there is a negative consequence from the use of masks; cleaning products, such as sanitizers; and gloves made from materials, which not only increase the sustainable production of a particular country but also reduce the environmental sustainability [26]. Thus, the fluctuation between sustainability and global production is a concern, as [27] describes how primary sector production (such as agriculture, petroleum, and oil), secondary sector production (such as manufacturing), and tertiary sector production (such as education and finance) are all in a shambles as a result of supply chain disruptions and self-isolation policies [28].

Nonetheless, the COVID-19 experience might be viewed as having important worldwide ramifications for the natural world, and while there is ongoing research about this pandemic, this novel coronavirus illness is impacting all the sustainable production, consumption, and economies of the world, notably China, the United States, the United Kingdom, India, etc. Medical service staff, governments, and all the people of the world need to show solidarity and work together to end or at least control the pandemic [28]. Thus, this study sets out to identify the critical gaps in our knowledge and, based on the systematic reviews of the literature, suggests the policies to be implemented. In the Web of Science (WOS), however, there are almost 6000 references [29], and 8000 references in 
Science Direct [30] about the studies of COVID-19. However, few people have mentioned the global impact of COVID-19 on the environment and advised research into sustainable production methods.

\section{Materials and Methods}

The methodology looks at potential scenarios of the present pandemic and attempts to characterize the level of evidence so that readers can engage in rigorous, critical thinking. Secondary data is used to identify the sustainability challenges and what previous studies have suggested and conclusions reached [7,31,32]. To date, the data from COVID-19 is still in its infancy but is being gradually aggregated for analysis. To have a clearer picture of the issue, the information in this paper was collected from materials published in various media outlets, research agencies, policy papers, newspapers, etc. The main focus of this study was to summarize how the COVID-19 pandemic affects the environment and what the total impacts are on sustainable production.

COVID-19 has already had an impact on the world, and this is not only due to the disease itself. In order to avoid repeating today's hard-won lessons in future pandemic preparation research, scientists must conduct current and future research publicly and freely. This means that reducing COVID-19 transmission while also having a positive impact on the environment and sustainable productions, society, the economy, and worldwide prevention measures are the key objectives of future work. Thus, the methodology (Table 1) utilized in this exploratory study started with a review of how the COVID-19 pandemic exacerbated global health, identifying the changeable features and structural alterations that made a difference in the built environment, and analyzing examples of such infections and changes to apply new global rules and regulations and understanding what controllable strategies and anticipations emerge from rethinking sustainable production.

Table 1. Methodological step.

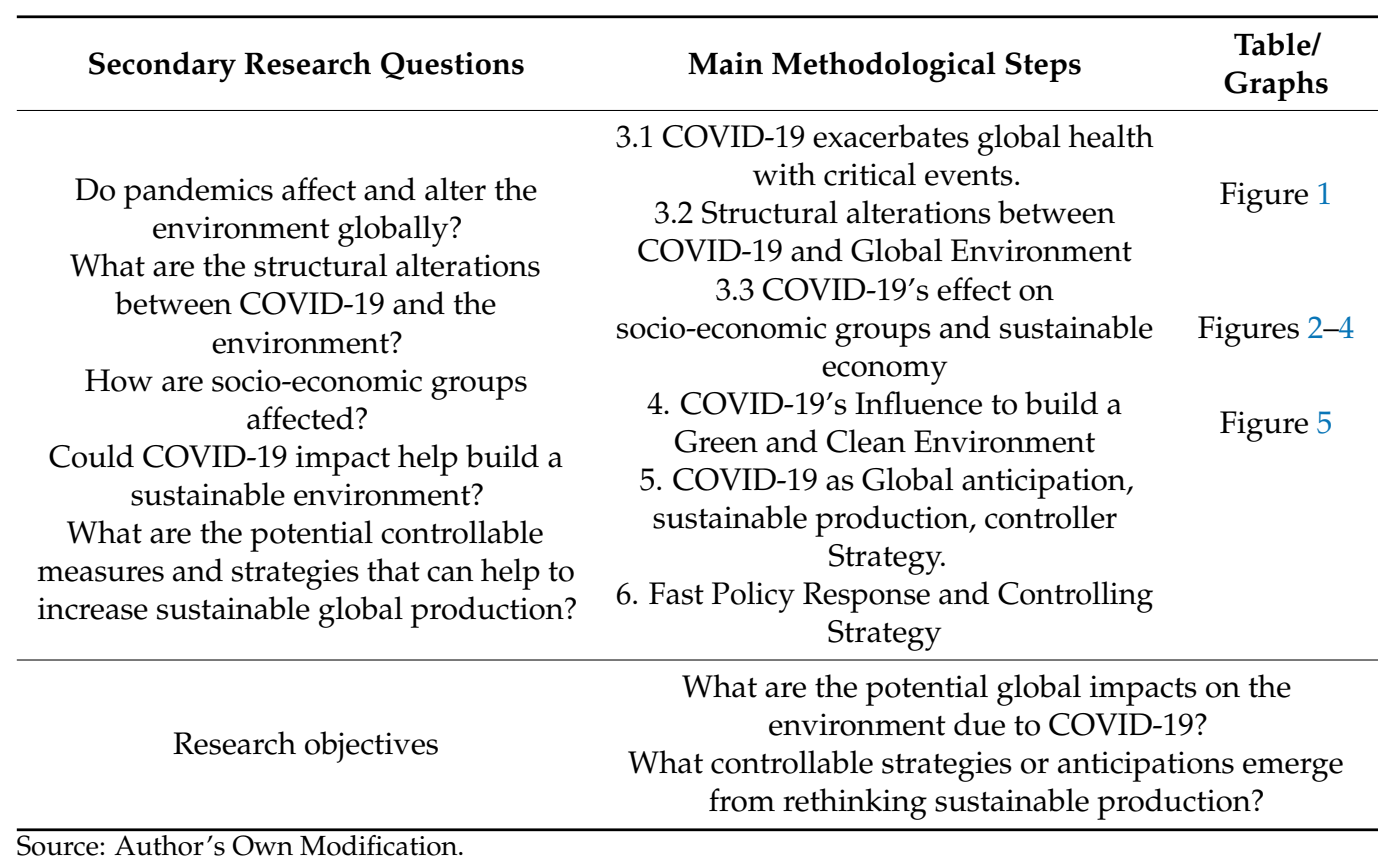

\section{Discussions}

\subsection{COVID-19 Exacerbates Global Health and Alters the Environment Globally}

COVID-19 is a highly infectious virus that can be spread by person-to-person contact and large crowd meetings [33]. Close interaction between individuals or groups of people exacerbates COVID-19's current maladies [4]. Fever, cough, tiredness, and breathing trouble are all indicators of a serious respiratory disease, according to [1], and the clinical range for patients infected with COVID-19 is moderate to nonspecific symptoms [34]. Nonetheless, 
the authors of [35] added to the findings of the study that the disease is transferred mostly by a hacking cough, sneezing, wheezing, and respiratory beads of perspiration, as well as from touched things like canned goods. These vaporizers enter the human body (respiratory framework) through inward inhalation through the nose or mouth [36,37]. Patients with more significant symptoms, such as acute respiratory pneumonia and septic illnesses, are more likely to be infected with the Coronavirus [38]. Besides, there is a traumatic significant relationship between COVID-19 and a rheumatologic patient, as rheumatic patients' recovery rate is rare among infected people [3]. Furthermore, the malady is a respiratory ailment that harms lung tissue and can spread to several organs, which ultimately causes human deaths. Hence, the authors of [39] emphasized global, societal, and individual preparedness for such maladies to protect global health from potential impacts. Thus, COVID-19 is now the world's most important clinical issue and a health trigger for people of various ages.

Additionally, the World Health Organization (WHO) declared COVID-19 a pandemic, and persons should be quarantined at home to prevent the spread of infectious diseases around the world [4]. Recent data from [40] shows that 213 countries were involved in recent pandemics, with 238,079,452 illnesses and 48,59,207 deaths. When the Coronavirus moved quickly from Wuhan, China to the rest of the world, clinical health organizations strove to create big regulations and administrative strides [3]. In the meantime, the administration made it mandatory for everyone to wear clinical masks and hand gloves and enacted legislation for the disposal of facemasks and other clinical waste to ensure environmental sustainability [41]. More recently, the authors of [35] determined that masks should not be used for more than $8 \mathrm{~h}$ because a disease could attack beyond that time, and that after discarding the masks, users should promptly wash their hands with sanitizer.

However, recent observations show that there are fewer people-especially cleaners, city workers, and community workers-who are aware of the danger of the diseases and the proper use and disposal of protective materials, such as masks and hand gloves, which creates waste in the environment. Hence, the critical events have exacerbated the new maladies, such as hepatitis and meningitis, with the recent COVID-19 pandemic [17], and these medical wastages can create bacteria, during human food consumption by several flying animals, which causes bacterial growth on human organisms [42]. Figure 1 depicts how Coronavirus affected the human body, which protective bio-medical materials-such as masks, gloves, hand sanitizer, etc.-creates the demand, and how biomedical products affect the environment caused by improper use of materials. Undeniably, the recent prices of masks, hand sanitizer, and gloves have increased suddenly and dramatically when millions of people started to use them daily. However, the demand for raw materials creates some opportunities for sustainable productions [21].

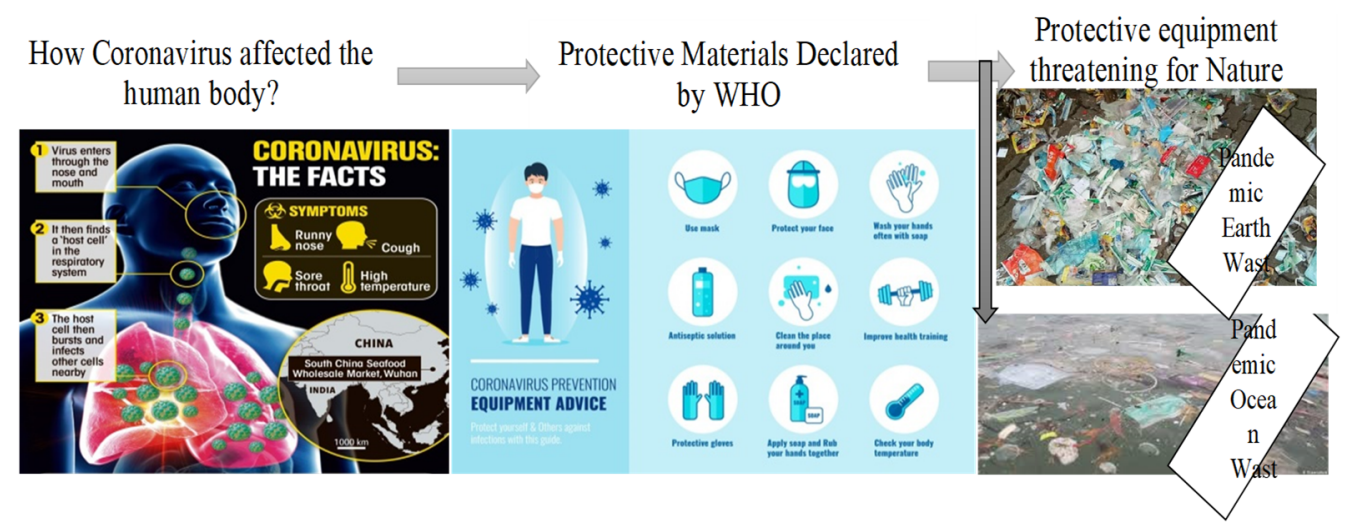

Figure 1. How pandemic materials affected the environment? Source: Author's own modification (2020).

Thus, the COVID-19 outbreak has become a clinical threat to millions of individuals and healthcare workers all around world, and has resulted in the death of many, partic- 
ularly those with weakened immune systems. As a result, developing a safe and stable COVID-19 vaccination was a pressing matter. In laboratory and in vivo investigations conducted internationally, antiviral medications, such as chloroquine and hydroxychloroquine, were effective against COVID-19 [43]. Remdesivir and chloroquine were reported to be significantly effective in reducing $2019-\mathrm{nCoV}$ in vitro in a recent study $[3,35,44,45]$. As a result, the role of research will continue to remain critical in the development of innovative medications or third doses of COVID-19 vaccinations to effectively prevent and control illnesses, safeguarding the worldwide physical condition.

\subsection{Structural Alterations between COVID-19 and Global Environment}

To meet the challenge of the growing population, urbanization and industrial development have grown and the consequences have proven to be detrimental to the global environment [46-48]. In addition, environmental concerns include water pollution, air pollution, ozone depletion, global warming, climate change, and depletion of groundwater levels and biodiversity [49,50], along with ecosystem change, arsenic contamination, and many others [51-53]. The increased concentration of greenhouse gases causes global warming $\left(\mathrm{CO}_{2}, \mathrm{CH}_{4}, \mathrm{~N}_{2} \mathrm{O}\right.$, etc. $)$, and environmental pollution has today become a major problem [54,55]. However, during the recent and ongoing COVID-19 pandemic, there are positive structural effects and alterations of the environment and remarkable changes in climate, resilience, and energy consumption [24], as almost all large and small towns and villages around the world have been affected, many of which have been in part or total lockdown over an extended period of time, ranging from a few weeks to several months [21]. Meanwhile, all local and central governments around the world have banned the free movement of their citizens to prevent community transmission, and many religious, social, cultural, sporting, scientific, and political events have been cancelled.

In the meantime, attempts to restrict the spread of SARS-CoV-2 by limiting movement have had a remarkable ecological effect [34], such as how the industry lockdown and nonfunctioning machines has brought about lower levels of waste emissions, carbon emissions, water consumption, and air pollution. On the other hand, there were far fewer vehicles on the roads, resulting in almost zero emission of greenhouse gases and small toxic particles in the environment [21]. Thus, due to the COVID-19 epidemics, the demand for energy in industries and the use of fossil fuels or conventional energy sources has been drastically reduced, and as a result, the emissions from $\mathrm{CO}_{2}$ and the ozone layer are balanced to some extent. In many large cities, residents are experiencing clear atmospheres for the very first time in their lifetimes. The pollutant level in tourism destinations, such as forests, marine beaches, mountainous areas, etc., has also decreased considerably, as the epidemic has shown different consequences on human civilization and has had a significant beneficial influence on the global environment.

\subsection{COVID-19's Effects on Socio-Economy Groups and Sustainable Economy: How Are They Affected?}

The recent SARS-CoV2 has not only impaired public health but also disrupted the socio-economy and physiological nature [56]. The authors of $[27,57]$ found that large socioeconomic groups, especially poorer communities in rural and urban areas, daily wageearners, and low-income groups, are affected more, due to low levels of hygiene and less education during the recent malady of COVID-19. Forests also encompass more than $30 \%$ of the Earth's land surface, according to the World Wildlife Fund. The unlimited growth in the human population has led to deforestation for reserves, production, and land for farming and cropping. As a result, average sea levels are increasing, and natural disasters are becoming more common, affecting not only the global land and ecology but also human health care [58]. Deforestation has also been connected to a variety of diseases spread by birds, such as bat-borne viral epidemics [59,60]. The COVID-19 pandemic is transmitted through bats. However, due to large populations and high production for consumers, the global unsustainable practices are linked to damage of the environments [17]. For example, due to the high demand by an ever-increasing population, the consumption rate of meat is 
dramatically increasing [61]. However, [62] warns that the high rate of meat consumers could be one of the prominent causes of pandemic manifestations, and COVID-19 is one of the examples, with infected bat meat consumers in Wuhan city, China [63]. Hence, the study identified several factors by which pandemics affect socio-economy and what immediate remedies exist for overcoming such maladies:

- Overpopulation and Family Size in Urban Areas:

Overpopulation is directly responsible for degrading the environment in urban rather than rural areas, and COVID-19 is one of the infectious diseases that spreads from human to human. Hence, globalization causes a population shift from rural to urban, and urbanization is responsible for the social consequences of infectious diseases [64]. Moreover, for the consequence of social malady, large families are more likely to spread COVID-19 than single or small families. In urban settings, some large families are more highly affected due to mass gatherings in a small house with poor sanitation, and therefore, the latest technology is ineffectual to mitigate any type of risk from a pandemic, due to the unsustainable environments in mass gathering areas [65]. Hence, socio-economic factors are undoubtedly a key concern.

- Does social distancing and self-isolation affect the socio-economy:

The recent epidemiology of SARS-CoV2 has brought about the implementation of new rules on social distancing and self-isolation with quarantine [1] since it surfaced in Wuhan, China in 2019. Hence, societal organizations have followed the international and national policies by implementing rules to work from home to avoid infectious diseases [65]. Hence, social distancing causes a large negative effect among middle, lower-middle, and lowerincome groups, because working at home may reduce interactions among people, but it is only available to certain people who are focused on jobs and connected to a stronger educational, social, and economic status [26]. Nevertheless, it creates disturbances among mass gatherings of people in small spaces. More significantly, it has been observed that a wider group of people emerges, of those who are unaware of the need to avoid mass gatherings or do not want to maintain social distances, and thus, they seemingly behave differently within the total environment among the various socio-economic groups [66].

The study observed that some people with serious pre-existing medical issues, like diabetes, respiratory illness, heart disease, or even hypertension and malignancy, are at greater risk, and a high proportion of deaths can be predicted from several areas of society as well as observed suicidal deaths due to uncertainty and high stress among the unemployed $[67,68]$, and yet undeniably some people are not maintaining the social distancing rules [69]. Admittedly, the SMEs, daily wage earners, and the employers of tourism companies, restaurants, aviation companies, small shops, and educational institutions have terminated their employees, especially in the LDCs and developed countries during the lockdown in 2020. Hence, there was an increase in unemployment of $14.7 \%$ during the recent pandemic, as declared by the US itself [70].

- The Transient Situations of the COVID-19 affecting the Sustainable Economy:

The global economy is a key concern regarding the environmental aspect, and it brings up various economic issues. Due to lockdowns and limited work options, the markets of agriculture, oil and petroleum, tourism, manufacturing, information technology (IT), media, research and development, food, and education sector [27,71], financial, aviation, and the healthcare and pharmaceutical industry are highly affected and upturned as the world's economy is in turmoil [72,73]. For instance, the British Plastics Federation [74] surveyed UK manufacturers to ask how COVID-19 has impacted their business operations: $98 \%$ of the respondents anticipated serious negative impacts and $80 \%$ mentioned a decline in their business operations over the next two quarters. Meanwhile, China, Italy, and the southern hemisphere are struggling to recover from the pandemic yet restrict foreign travelers from frequenting beaches [75]. European and North American nations have not yet reached the peak of the epidemiological curve, but Italy showed that the country's present GDP is 2.02 USD trillion (net loss), from USD 2.9 trillion [76]. Nonetheless, the study 
mentioned that the second wave will be more devastating than the first, in comparison to other epidemics in history [77].

For instance, Figures 2-4 depict how the pandemic affected the world product exchange volume and export, imports, and GDP in North America, South and Central America, Europe, Asia, and other continents. Exports dramatically reduced in 2020 (almost -36.2) when comparing the fiscal years of 2018 and 2019, but global economists and policymakers have anticipated that exports will increase proportionately in Asia in 2021 (36.1\%), especially in the last six months of 2021, as opposed to the situation in Europe, North America, and South and Central America [78], as shown in Figure 2. Furthermore, Figure 3 depicts the chronological, enthusiastic, and unenthusiastic development of imports during the malady of COVID-19. As in 2021, South and Central America experienced dramatically decreased imports during the first six months $(-22.2 \%)$ and the last six months of 2020 $(-43.8 \%)$, whereas it is anticipated that the import rates will increase in North America (29.5\%) followed by Asia, Europe, South and Central America, and others respectively. Alongside, Figure 4 illustrates the relationship between gross domestic product (GDP) and product exchange volume from 2018-2021. The GDP rate fell in South and Central America (-10.8), followed by Europe, North America, Asia, and other countries in 2020 during the COVID-19 pandemic. Nonetheless, it is anticipated that the GDP will climb in Asia (7.4\%) in 2021 and may lower proportionally in South and Central America (4.8\%). However, all over the world there is widespread concern to mitigate the environmental risks, which are associated with socio-economy and community wellbeing. Nevertheless, the manufacturing industry and power plants that halted their productions and the fewer vehicles on the roads have brought about greater positive impacts on the environment, and air pollution and greenhouse gas emissions (GHGEs) were dramatically reduced, especially in overpopulated countries [79].

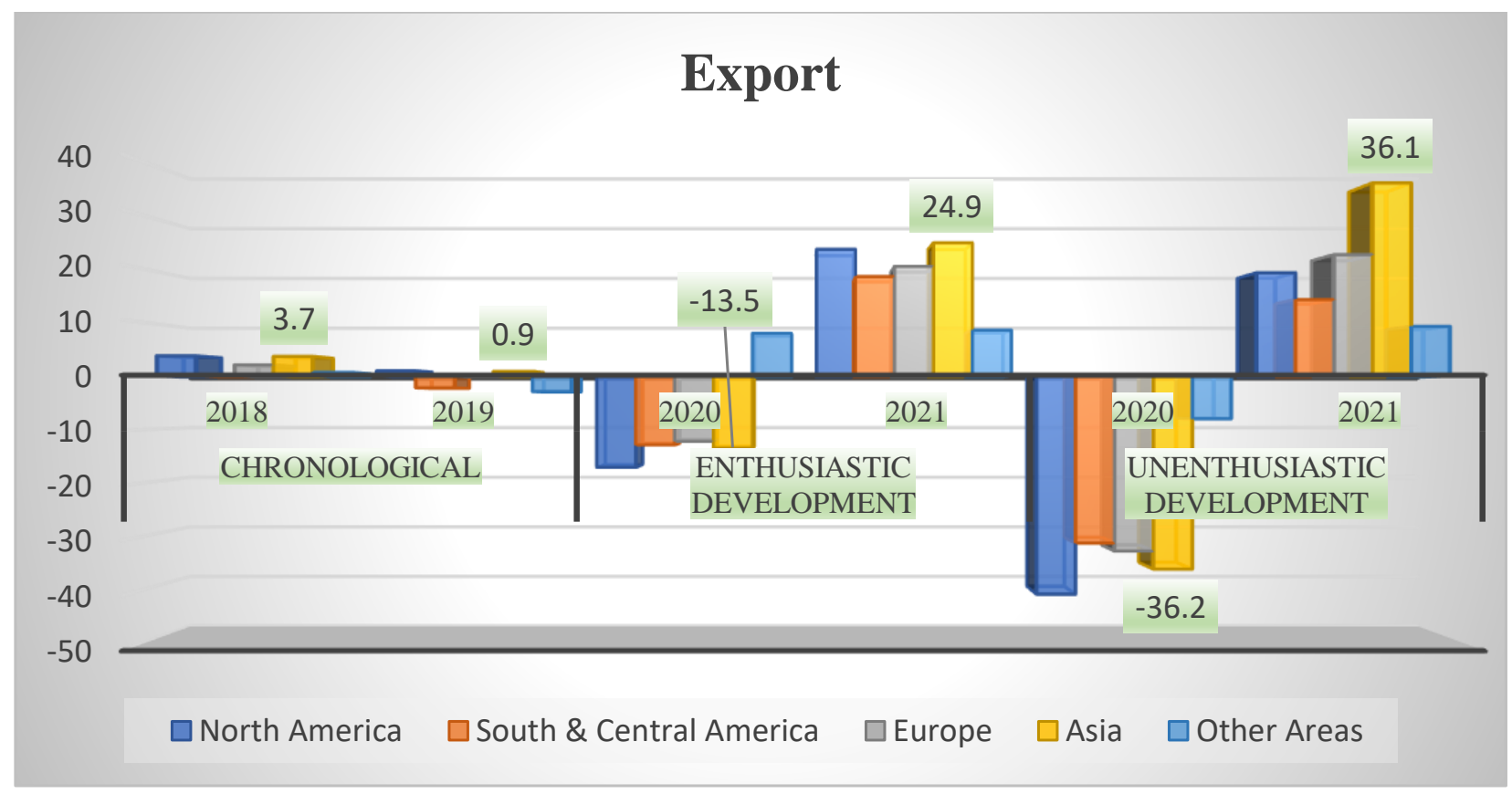

Figure 2. Product exchange volume and real GDP in 2018-2021 (yearly \% change). Source: [78,80] IMF (2020). 


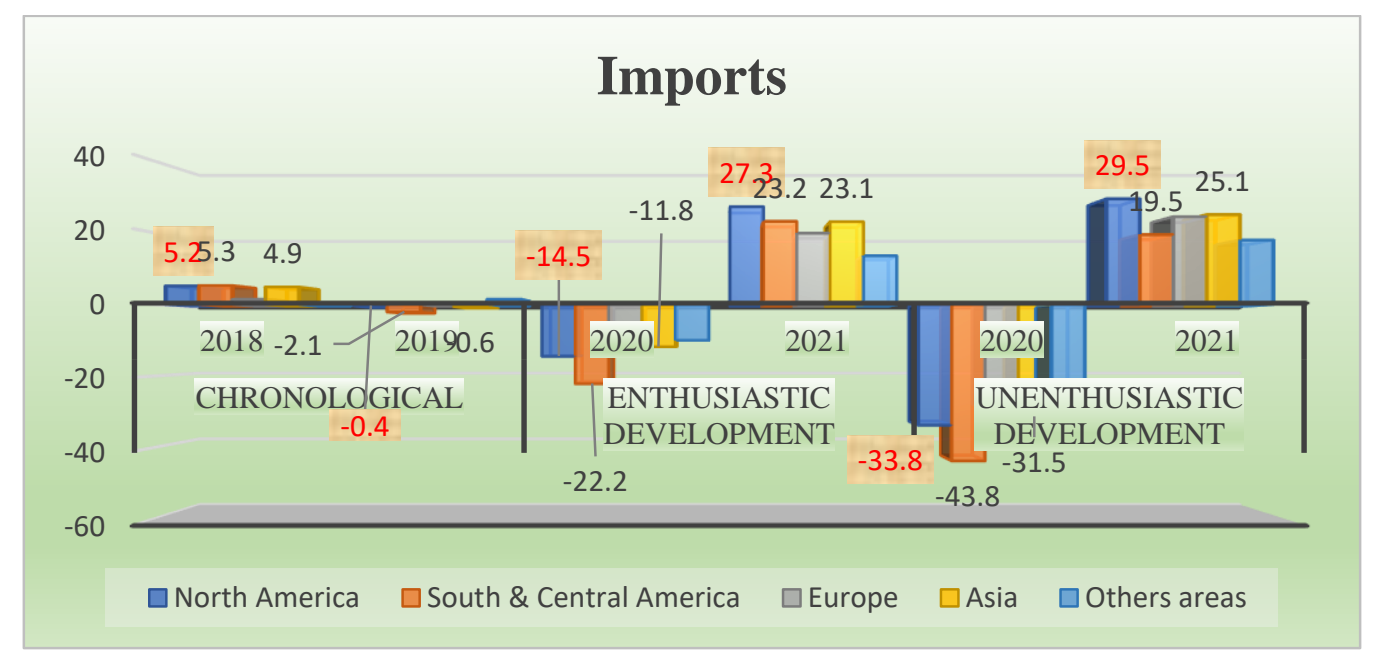

Figure 3. Product exchange volume and import in 2018-2021 (yearly \% change). Source: [78,80].

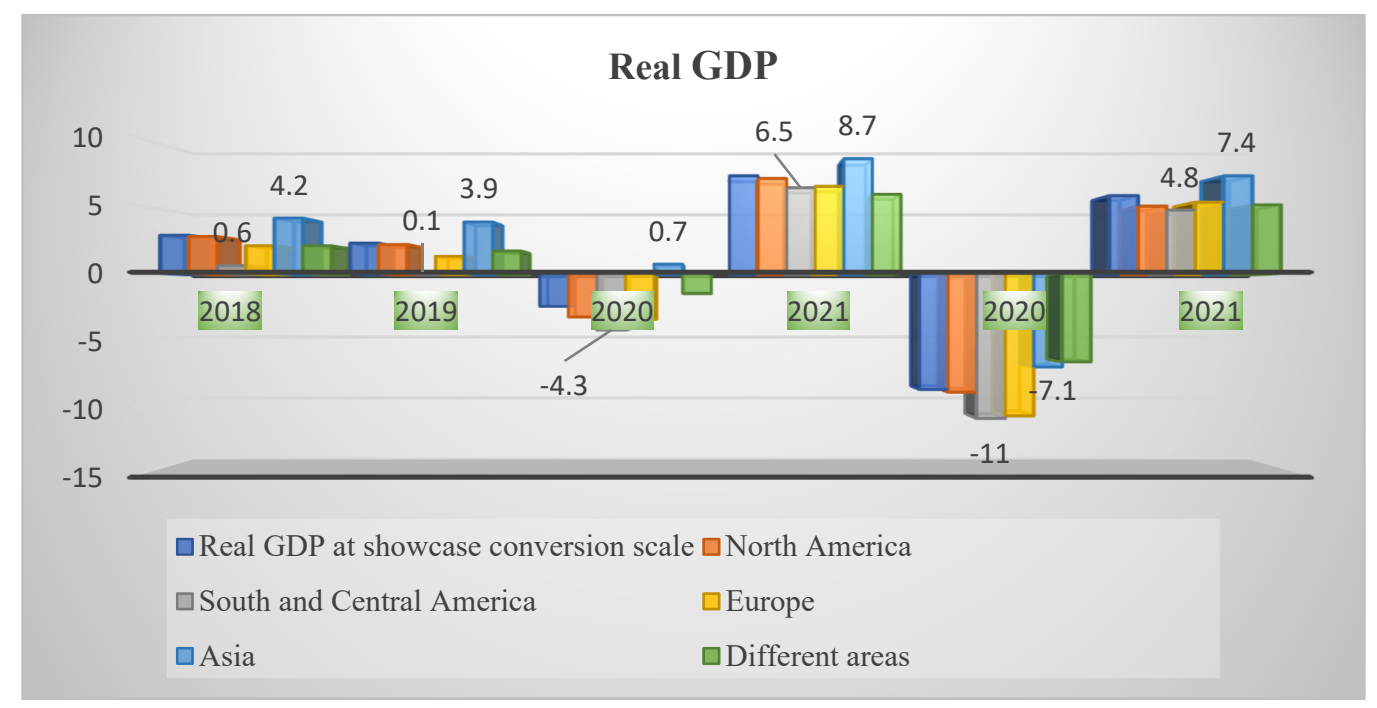

Figure 4. Product exchange volume and real GDP in 2018-2021 (yearly \% change). Source: [78,80].

\section{COVID-19 Influenced the Construction of a Green and Clean Environment}

The main aim of the research focused on the indirect positive and negative effects on the environment. For example, in London, the usually busy clubs, theatres, and other public places have been shuttered, individuals have been advised to stay at home, and flights have been cancelled [81]. All these changes, however, have resulted in some unforeseen global implications, including a reduction in the death rate. Furthermore, industries, transportation networks, and all other forms of non-essential activities have shut down, resulting in a sharp reduction in carbon emissions and other gases. Due to steps taken to limit the spread of the virus, air pollution levels in New York have decreased by over $50 \%$ compared to last year. In China, emissions data showed a $25 \%$ reduction at the start of the year as people were urged to remain at home, companies were closed, and energy use at the country's main energy plants has decreased by $40 \%$ since the last three months of 2019 . The amount of high-quality air in more than 330 cities across China increased by $11.4 \%$ compared to the previous year, as per the Ministry of Ecology and Environment. As seen in satellite photos, nitrogen dioxide $\left(\mathrm{NO}_{2}\right)$ emissions in Europe decreased over northern Italy, the UK, and Spain [82]. Figure 5 illustrates SARS-CoV2's indirect positive and negative impacts on the green ecosystem, especially in Spain, France, Germany, China, and Italy, with a reduction of $\mathrm{SO}_{2}, \mathrm{CO}_{2}$, and $\mathrm{NO}_{2}$ concentrations $[83,84]$. Previously, environmental problems were always associated with higher $\mathrm{SO}_{2}, \mathrm{CO}_{2}$, and $\mathrm{NO}_{2}$ levels [85]. 


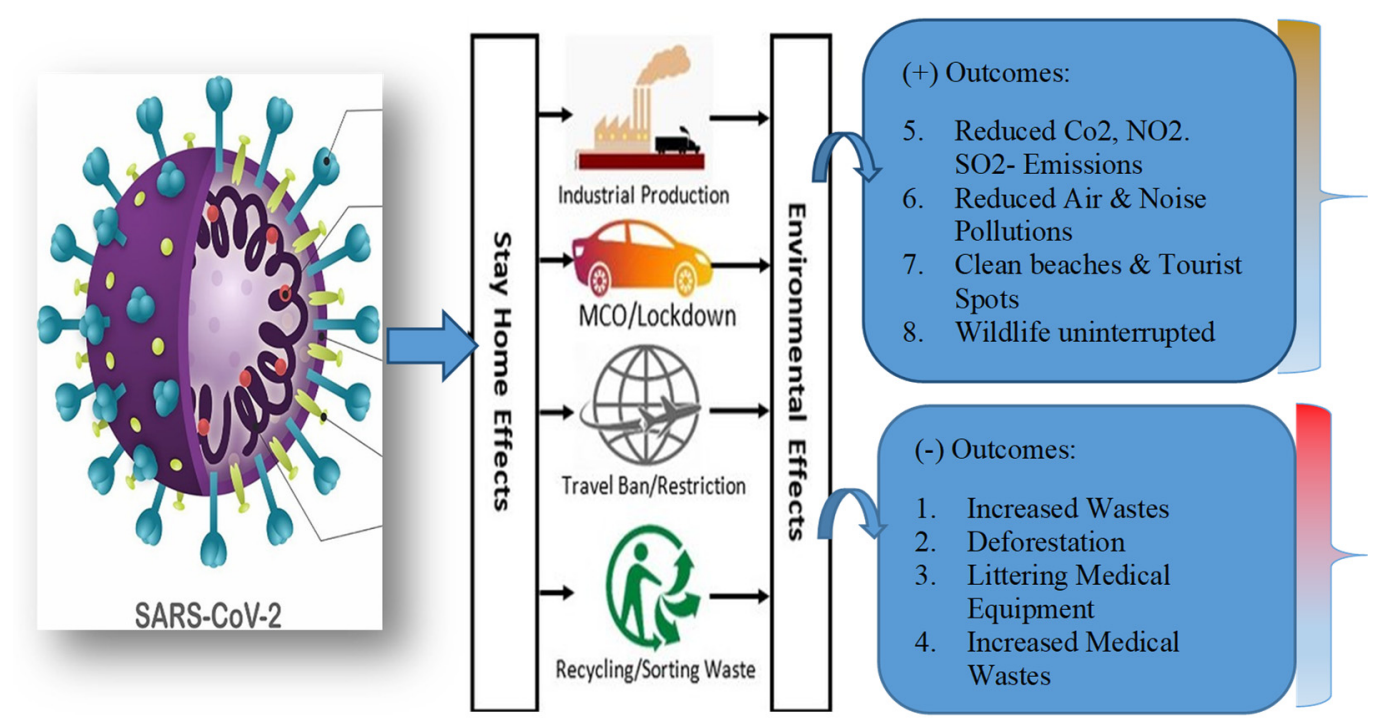

Figure 5. SARS-CoV2's effect on the green and clean environment $( \pm)$. Source: Author's own modification (2020).

Thousands of jobs have been lost because of the outbreak, which has put millions of people's livelihoods in jeopardy as businesses struggle to keep up with the virus's spread. Economic activity has slowed, and stock markets have fallen in lockstep with reduced carbon emissions. Many environmentalists, on the other hand, have long advocated for a decarbonized, sustainable economy. A pandemic like this, which has claimed the lives of thousands of people, cannot be viewed as a means for bringing about environmental change. When the pandemic fades and carbon and pollution emissions return, it will be as if this clear-sky period never existed, and the changes we see now will have no long-term consequences [86].

Another unexpected ecological effect of the coronavirus was identified in Venice, Italy, where the pandemic has reduced the number of tourists and allowed the waterways in Venice's canals to improve. The pristine water, as well as the return of fish to the canals in replacement of the motorboats, sediment churning, and other water-related pollution activities, astounded the public. Another result of the coronavirus is a considerable decrease in coal use, which is good for the environment and has contributed to a large-scale reduction in air pollution in China $[83,84] . \mathrm{CO}_{2}$ and nitrous oxide levels have also reduced in the atmosphere. Residential energy usage is predicted to grow as more people work from home these days. According to data, in the United States, this usage has climbed by 6 to $8 \%$. This epidemic will save energy and may have an influence on reducing the use of polluting fuels in power plants, because the demand for polluting fuels in power plants has reduced [87]. Air quality has improved in numerous cities around the world as a result of the COVID-19 outbreak. Several billions of dollars are being spent on research to find a diagnosis, treatment, and medication to stop the spread. However, essential preventative tactics, such as forestation and proper maintenance of wildlife habitats, are being overlooked. As a result, it is vital that society recognizes the importance of forests, promotes afforestation as much as possible, and raises awareness about the issue.

\section{COVID-19 Regarding Global Anticipation, Sustainable Production, and Control Strategy}

To avoid the global circulation of COVID-19 infection, control activities and public health services are urgently required to alleviate the virus's damage and increase sustainable output. However, the resilience of agricultural commodities is less in demand, with lower prices that have dropped by $20 \%$, caused by the reduced supplies of raw materials in hotels and restaurants [71], and that have flattened the curve of animal pharmaceuticals drug suppliers [88]. The global production of the chemical industry dropped by $1.2 \%$, 
indicated as one of the major causes of the financial crashes after 2008, contributing to a slowdown in predicted growth [89]. However, the COVID-19 pandemic has dampened the prices of petroleum and oil worldwide unprecedentedly, and Saudi Arabia has retaliated with attractive discounts (25\%) for global buyers [90]. Hence, the production of agricultural commodities, chemicals, animal pharmaceuticals, and petroleum and oil has seized the unsustainable economy.

Additionally, panic buying and food hoarding by consumers has put the food system, especially food delivery and retailing, under strain [91]. As a result, food shortages of long shelf-life milk, pasta, rice, and tinned vegetables have become a bigger issue [92]. Furthermore, quarantine policies have increased the consumer demand for internet shopping with home delivery [93] and excessive bookings [91]. However, the unlimited stockpile has increased the tensions for the vulnerable populations who are unable to pay and SMEs [94,95].

As a result, the amount of organic garbage produced by families has increased. Inorganic waste has also increased because of packing materials. The amount of medical waste produced is likewise increasing. During the epidemic, a total of 240 metric tons of medical waste were produced per day by Wuhan hospitals, compared to a prior average of fewer than 50 tons. There has been a surge in personal protection equipment rubbish, such as masks and gloves, in other countries, such as the United States [96]. However, it was clarified that waste recycling is one of the resources from sustainable production used to conserve natural resources and save energy [97,98], but the production from waste recycling is restricted because of social distancing and partial lockdown [80]. Besides, [99] asserted that the restriction to produce and repeal disposable bags seized the industrial economy. Hence, the reduction of waste recycling products, such as biofuel and biomass, are seizing the industry as well the sustainable economy, especially in European countries, the USA, Italy, and other countries.

Nonetheless, many experts have encouraged governments around the world to outlaw animal markets and transactions permanently to protect human lives [99]. As the COVID19 outbreak began in the Hunan seafood market in Wuhan, China, these efforts may serve to safeguard human life from upcoming epidemics. Wildlife markets, where animals like civets, bats, wolf pups, pangolins, and other tiny creatures are kept alive in small cages, have been temporarily banned in China, even though $60 \%$ of developing transferrable illnesses are thought to start in animals, and approximately $70 \%$ of these are thought to begin in animals in the wild. As a result, in the interests of public health and national security, it is critical to prohibit wildlife marketplaces and wildlife exchanges worldwide to reduce the possibility of new viruses arising.

\section{Fast Policy Response and Controlling Strategy}

COVID-19 is a well-known worldwide threat that necessitates a worldwide response involving every government on the globe. To contain the current outbreak, broad steps are needed to decrease coronavirus transmission from person to person. Highly vulnerable people, such as youth, healthcare personnel, and the elderly, should be protected through special restriction tactics and measures [13]. For medical professionals, healthcare providers, individuals, and public health researchers interested in working on the coronavirus, a guide has already been produced [31]. The elderly are disproportionately affected by the coronavirus epidemic, owing to their compromised immune systems, which allow viral infections to spread rapidly. Facilities must provide decontamination reagents to disinfect hands several times a day [41].

Physical contact and wet objects have also been examined as possible routes of transmission when treating coronavirus. To restrict and prevent the virus's spread, China and a few other countries, notably the United States, have instituted travel tests. Epidemiological changes in coronavirus infections should be observed. It is crucial to consider various transmission channels and subclinical infections, as well as virus adaptation and progression in people and potential intermediates and reservoirs. Furthermore, there 
are numerous questions that remain unanswered. They include information, such as the overall number of people who have been tested, how many have tested positive, and if the number remains constant or changes [100]. As a result, the limiting of mass gatherings is an important and fundamental preventative strategy in the public health care system for reducing SARS-CoV-2 transmission. Furthermore, the use of media and information technology supports society in the prevention and control of the COVID-19 outbreak.

Policies, such as the "stay-at-home policy" and "social distancing policy", on the other hand, have significantly destroyed the earnings of restaurants, bars, stores, and hotels, as well as the manufacturing industry in many locations, leading to their closure in some cases. It has devastated many enterprises in the service, manufacturing, food, and financial industries in unexpected ways, and many governments have refused to accept responsibility for the failure of small and major firms that closed because of the government's social distancing policy and lockdown limitations. Nonetheless, it was expected that the social distancing strategy would be applied too soon or taken to its logical conclusion by people and travelers who were scared to frequent such establishments for fear of causing the COVID-19 sickness, as [56] found.

\section{The Implication of the Findings}

Overall, the study indicates that at the height of the coronavirus crisis, decisions on global health policy, the increasing number of lockdown days, and foreign travel limitations negatively impacted the general environment, socioeconomic activities, and the opening, lowest, and maximum prices, and output of the main industrial sustainability indices. The imposed restrictions on internal and international movement and national policy spending, on the other hand, had a positive impact on environmental conservation and socioeconomic activities, but the number of confirmed cases was positively related to the opening, highest, and lowest consumer prices of medical garbage, medicine and food beverage production, and online purchasing. The findings imply that the global supply chain and policymakers should support and protect small and medium enterprises (SMEs), industry, and manufacturers by providing guarantees to banks and several micro-lenders. This appears to be more effective than keeping restrictions on the environment and global health to mitigate the risks of COVID-19. Every country's government should introduce new legislation to protect the livelihoods of citizens from unemployment risks and industry production policies that are essential to reboot the sustainable economy after the health pandemic is over. As a result, legislation like this can help to keep household income stable and preserve industry's productive capacity, human capital, and the entire economy while also preserving the environment.

\section{Conclusions and Suggestions}

Humans have been trying to protect and replenish nature for the past few decades, but they have not succeeded completely since the beginning of the 21st century. Transmitted infections are now the world's most important clinical issue, particularly for all people of various ages. However, the lockdown and social distancing restrictions during the pandemic have brought about positive impacts on the environment and on global climate change. Moreover, the mutually effective bond between humans and nature has improved the environment and built a strong correlation between the environment and sustainability in this pandemic. Whether or not more or fewer changes are made to the greening and cleaning of the environment, the support provided in fighting pandemic illnesses will change. The study also discovered that social confinement has a win-lose relationship with both health and economics, as well as livelihood implications (job loss) and potential positives in some environmental dimensions, such as reduced air pollution, expanded energy reserves, and reduced water usage. The parallel study referenced by [17] also identified how this pandemic has leveraged sustainability by rebuilding the ecosystems.

A structural change between the environment and sustainability occurs when the viable solution components and the triggers for a necessary change converge, according 
to the study. As a result, it is critical to provide the ability to discover solutions, make modifications, and evolve in a variety of other areas besides health, such as regarding economic, social, and environmental concerns. It is crucial to overcome the disease (virus). The transmission path must be cut off, and the disease must become actively controlled by using existing drugs and available resources. Like all previous calamities on the Earth, it is hoped that mankind can overcome the epidemic in a short time, but it must recognize the limits that nature can reach before it is too late to handle the epidemic.

The study provides a unique contribution to the subject by connecting the research from many worldwide pandemic catastrophes and challenges to the environment, providing a structural correlation between the environment and sustainability, and illustrating the anticipatory measures and changes for controllable strategies for increasing sustainable production and consumption, formulating new rules on human growth rates, and banning wildlife trade. The study also contends that a few socio-economic groups are at higher risk than others, as community well-being is affected more in urban areas than in rural areas. However, it is notable that the supply and demand for masks, hand sanitizer, and gloves, etc. has increased dramatically as millions of people have started to wear masks and clean their hands with sanitizer daily to avoid the spread of diseases. Hence, the environment is also affected due to high consumption of these products. Moreover, the study has interlinked the consumption of medicine and sustainable production to repeal the infection rate of COVID-19 in order to build resilience. The study emphasized that with the implementation of a broader controllable strategy, anticipatory measures can emerge from rethinking sustainable production. Such solutions, however, necessitate the assurance of a flexible approach as well as much more research. Therefore, the study suggested that the current options for sustainable production must be measured and require further research.

Author Contributions: Conceptualization, H.B.; methodology, H.B.; software, H.B. and A.S.A.F.A.; formal analysis, H.B.; investigation, H.B.; resources, H.B.; writing—original draft preparation, H.B.; writing-review and editing, H.B. and A.S.A.F.A.; visualization, H.B., A.S.A.F.A. and W.L.F.; supervision, H.B. and A.S.A.F.A.; funding acquisition, W.L.F. and A.H.A., English Check \& Proofreading, W.L.F.; added professionally, A.B.A.G. All authors have read and agreed to the published version of the manuscript.

Funding: The APC was funded by Malaysian Palm Oil Board (MPOB), Universiti Kebangsaan Malaysia (UKM) Endowment Chair (Project Code: MPOB-UKM-2020-009) which is headed by Abd Hair Awang.

Institutional Review Board Statement: Not applicable.

Informed Consent Statement: Not applicable.

Data Availability Statement: Not applicable.

Conflicts of Interest: The authors declare no conflict of interest.

\section{References}

1. World Health Organization (WHO). Coronavirus disease 2019 (COVID-19) Situation Report-38. 2019. Available online: https: //www.who.int/docs/default-source/coronaviruse/situation-reports /20200227-sitrep-38-covid-19.pdf?sfvrsn=9f98940c_2 (accessed on 28 February 2020).

2. Huang, C.; Wang, Y.; Li, X.; Ren, L.; Zhao, J.; Hu, Y.; Zhang, L.; Fan, G.; Xu, J.; Gu, X.; et al. Clinical features of patients infected with 2019 novel coronavirus in Wuhan, China. Lancet 2020, 395, 497-506. [CrossRef]

3. Wang, C.; Horby, P.W.; Hayden, F.G.; Gao, G.F. A novel coronavirus outbreak of global health concern. Lancet 2020, 395, 470-473. [CrossRef]

4. World Health Organization (WHO). Q\&As on COVID-19 and Related Health Topics. 2020. Available online: https:/ /www.who. int/emergencies/diseases/novel-coronavirus-2019/question-and-answers-hub (accessed on 26 May 2020).

5. Worldometer, S. Covid-19 Coronavirus Pandemic: Worldometer. 2020. Available online: https://www.worldometers.info/ coronavirus / (accessed on 11 June 2021). 
6. CSSE. Coronavirus 2019-nCoV, CSSE. Coronavirus 2019-nCoVGlobal Cases by Johns Hopkins CSSE. 2019. Available online: https://gisanddata.maps.arcgis.com/apps/opsdashboard/index.html\#/bda7594740fd40299423467b48e9ecf6 (accessed on 10 November 2020).

7. Velavan, T.P.; Meyer, C.G. The COVID-19 epidemic. Trop. Med. Int. Health 2020, 25, 278. [CrossRef] [PubMed]

8. Kooraki, S.; Hosseiny, M.; Myers, L.; Gholamrezanezhad, A. Coronavirus (COVID-19) outbreak: What the department of radiology should know. J. Am. Coll. Radiol. 2020, 17, 447-451. [CrossRef] [PubMed]

9. Tyrrell, D.A.; Bynoe, M.L. Cultivation of viruses from a high proportion of patients with colds. Lancet 1966, 1, 76-77. [CrossRef]

10. Ather, A.; Patel, B.; Ruparel, N.B.; Diogenes, A.; Hargreaves, K.M. Coronavirus disease 19 (COVID-19): Implications for clinical dental care. J. Endod. 2020, 46, 584-595. [CrossRef]

11. Zhou, P.; Yang, X.L.; Wang, X.G.; Hu, B.; Zhang, L.; Zhang, W.; Si, H.R.; Zhu, Y.; Li, B.; Huang, C.L.; et al. A pneumonia outbreak associated with a new coronavirus of probable bat origin. Nature 2020, 579, 270-273. [CrossRef]

12. Cao, Y.-C.; Deng, Q.-X.; Dai, S.-X. Remdesivir for severe acute respiratory syndrome coronavirus 2 causing COVID-19: An evaluation of the evidence. Travel Med. Infect. Dis. 2020, 35, 101647. [CrossRef]

13. Kucharski, A.J.; Russell, T.W.; Diamond, C.; Liu, Y.; Edmunds, J.; Funk, S.; Eggo, R.M. Centre for Mathematical Modelling of Infectious Diseases COVID-19 working group. Early dynamics of transmission and control of COVID-19: A mathematical modelling study. Lancet Infect. Dis. 2020, 20, 553-558. [CrossRef]

14. Li, M.; Lei, P.; Zeng, B.; Li, Z.; Yu, P.; Fan, B.; Wang, C.; Li, Z.; Zhou, J.; Hu, S.; et al. Coronavirus disease (COVID-19): Spectrum of CT findings and temporal progression of the disease. Acad. Radiol. 2020, 27, 603-608. [CrossRef]

15. Allocati, N.; Petrucci, A.; Di Giovanni, P.; Masulli, M.; Di Ilio, C.; De Laurenzi, V. Bat-man disease transmission: Zoonotic pathogens from wildlife reservoirs to human populations. Cell Death Discov. 2016, 2, 1-8. [CrossRef] [PubMed]

16. Gorbalenya, A.E.; Baker, S.C.; Baric, R.; Groot, R.J.D.; Drosten, C.; Gulyaeva, A.A.; Haagmans, B.L.; Lauber, C.; Leontovich, A.M.; Neuman, B.W.; et al. severe acute respiratory syndrome-related coronavirus: The species and its viruses-A statement of the Coronavirus Study Group. BioRxiv 2020. [CrossRef]

17. Pinheiro, M.D.; Luís, N.C. COVID-19 Could Leverage a Sustainable Built Environment. Sustainability 2020, 12, 5863. [CrossRef]

18. Yu, Z.; Razzaq, A.; Rehman, A.; Shah, A.; Jameel, K.; Mor, R.S. Disruption in global supply chain and socio-economic shocks: A lesson from COVID-19 for sustainable production and consumption. Oper. Manag. Res. 2021, 1-16. [CrossRef]

19. UNCTAD. The COVID-19 Shock to Developing Countries: Towards a "Whatever It Takes" Programme for the Two-Thirds of the World's Population Being Left Behind. United Nations Conference on Trade and Development, March 2020. UNCTAD Geneva, Switzerland. Available online: https://unctad.org/system/files/official-document/gds_tdr2019_covid2_en.pdf (accessed on 4 December 2020).

20. Van Bavel, J.J.; Baicker, K.; Boggio, P.S.; Capraro, V.; Cichocka, A.; Cikara, M.; Crockett, M.J.; Crum, A.J.; Douglas, K.M.; Druckman, J.N.; et al. Using social and behavioural science to support COVID-19 pandemic response. Nat. Hum. Behav. 2020, 4, 460-471. [CrossRef]

21. Paital, B. Nurture to nature via COVID-19, a self-regenerating environmental strategy of environment in global context. Sci. Total Environ. 2020, 729, 139088. [CrossRef] [PubMed]

22. Varona, L.; Gonzales, J.R. Dynamics of the impact of COVID-19 on the economic activity of Peru. PLoS ONE 2021, 16, e0244920. [CrossRef] [PubMed]

23. Eichenbaum, M.S.; Rebelo, S.; Trabandt, M. The Macroeconomics of Testing and Quarantining; (No. w27104); National Bureau of Economic Research: Cambridge, MA, USA, 2020.

24. Helm, D. The Environmental Impacts of the Coronavirus. Environ. Resour. Econ. 2020, 76, 21-38. [CrossRef]

25. International Energy Agency. Oil Market Report. February 2020. Available online: https://www.iea.org/reports/oil-marketreport-february-2020 (accessed on 4 June 2020).

26. Klemeš, J.J.; Van Fan, Y.; Tan, R.R.; Jiang, P. Minimising the present and future plastic waste, energy and environmental footprints related to COVID-19. Renew. Sustain. Energy Rev. 2020, 127, 109883. [CrossRef]

27. Nicola, M.; Alsafi, Z.; Sohrabi, C.; Kerwan, A.; Al-Jabir, A.; Iosifidis, C.; Agha, M.; Agha, R. The socio-economic implications of the coronavirus pandemic (COVID-19): A review. Int. J. Surg. 2020, 78, 185-193. [CrossRef]

28. Yoo, J.-H. The Fight against the 2019-nCoV Outbreak: An Arduous March Has Just Begun. J. Korean Med Sci. 2020, 35 , e56. [CrossRef] [PubMed]

29. Web of Science (WoS). 2020. Available online: https:/ / login.webofknowledge.com/ (accessed on 5 June 2020).

30. Science Direct (SD). 2020. Available online: https:/ / www.sciencedirect.com/ (accessed on 5 June 2020).

31. Mossa-Basha, M.; Medverd, J.; Linnau, K.; Lynch, J.B.; Wener, M.H.; Kicska, G.; Sahani, D.J.R. Policies and guidelines for COVID-19 preparedness: Experiences from the University of Washington. Radiology 2020, 296, E26-E31. [CrossRef] [PubMed]

32. Mitra, A.; Ray Chadhuri, T.; Mitra, A.; Pramanick, P.; Zaman, S. Impact of COVID-19 related shutdown on atmospheric carbon dioxide level in the city of Kolkata. Parana J. Sci. Educ. 2020, 6, 84-92.

33. Jones, D.S. History in a Crisis-Lessons for Covid-19. N. Engl. J. Med. 2020, 382, 1681-1683. [CrossRef]

34. Wilder-Smith, A.; Chiew, C.J.; Lee, V.J. Can we contain the COVID-19 outbreak with the same measures as for SARS? Lancet Infect. Dis. 2020, 20, e102-e107. [CrossRef] 
35. Wang, D.; Hu, B.; Hu, C.; Zhu, F.; Liu, X.; Zhang, J.; Wang, B.; Xiang, H.; Cheng, Z.; Xiong, Y.; et al. Clinical characteristics of 138 hospitalized patients with 2019 novel coronavirus-infected pneumonia in Wuhan, China. JAMA 2020, 323, 1061-1069. [CrossRef] [PubMed]

36. Phan, L.T.; Nguyen, T.V.; Luong, Q.C.; Nguyen, T.V.; Nguyen, H.T.; Le, H.Q.; Nguyen, T.C.; Cao, T.M.; Pham, Q.D. Importation, and human-to-human transmission of a novel coronavirus in Vietnam. N. Engl. J. Med. 2020, 382, 872-874. [CrossRef] [PubMed]

37. Riou, J.; Althaus, C.L. Pattern of early human-to-human transmission of Wuhan 2019 novel coronavirus (2019-nCoV), December 2019 to January 2020. Eurosurveillance 2020, 25, 2000058. [CrossRef] [PubMed]

38. Backer, J.A.; Klinkenberg, D.; Wallinga, J.J.E. Incubation period of 2019 novel coronavirus (2019-nCoV) infections among travellers from Wuhan, China, 20-28 January 2020. Eurosurveillance 2020, 25, 2000062. [CrossRef]

39. Jacobsen, K.H. Will COVID-19 generate global preparedness? Lancet 2020, 395, 1013-1014. [CrossRef]

40. World Health Organization (WHO). WHO Coronavirus Disease (COVID-19) Dashboard. 2021. Available online: https: / covid19. who.int/ (accessed on 9 October 2021).

41. Phan, T.L.; Ching, C.T.S. A reusable mask for coronavirus disease 2019 (COVID-19). Arch. Med Res. 2020, 51, 455-457. [CrossRef] [PubMed]

42. Hellewell, J.; Abbott, S.; Gimma, A.; Bosse, N.I.; Jarvis, C.I.; Russell, T.W.; Munday, J.D.; Kucharski, A.J.; Edmunds, W.J.; Funk, S.; et al. Feasibility of controlling COVID-19 outbreaks by isolation of cases and contacts. Lancet Glob. Health 2020, 8, e488-e496. [CrossRef]

43. Rolain, J.-M.; Colson, P.; Raoult, D. Recycling of chloroquine and its hydroxyl analogue to face bacterial, fungal, and viral infections in the 21st century. Int. J. Antimicrob. Agents 2007, 30, 297-308. [CrossRef] [PubMed]

44. Morse, J.S.; LaLonde, T.; Xu, S.; Liu, W.R. Learning from the Past: Possible Urgent Prevention and Treatment Options for Severe Acute Respiratory Infections Caused by 2019-nCoV. ChemBioChem 2020, 21, 730-738. [CrossRef]

45. Lu, H. Drug treatment options for the 2019-new coronavirus (2019-nCoV). Biosci. Trends 2020, 14, 69-71. [CrossRef]

46. Begum, H.; Alam, A.S.A.F.; Er, A.C.; Siwar, C.; Ishak, S. Economic Sustainability of Oil Palm Cultivation: Smallholder Perspective. Asian J. Poverty Stud. 2014, 1, 177-183. [CrossRef]

47. Begum, H.; Choy, E.A.; Siwar, C.; Alam, F.; Ishak, S. Smallholder's Practices towards Environment Sustainability. Adv. Sci. Lett. 2015, 21, 1742-1745. [CrossRef]

48. Begum, H.; Siwar, C.; Er, A.C.; Alam, A.S.A.F. Environmentally Friendly Practices of Oil Palm Cultivators. Int. J. Adv. Appl. Sci. 2016, 3, 15-19.

49. Alam, A.S.A.F.; Er, A.C.; Begum, H.; Siwar, C. Smallholders the Prominent Contributor in Oil Palm Sector for Sustainability. Int. J. Adv. Appl. Sci. 2016, 3, 20-24.

50. Begum, H.; Siwar, C.; Alam, A.S.A.F.; Choy, E.A.; Ishak, S.; Alam, L. Enhancing Sustainability amongst Oil Palm Smallholders in Malaysia. Int. J. Agric. Resour. Gov. Ecol. 2018, 14, 62-79. [CrossRef]

51. Bremer, S.; Schneider, P.; Glavovic, B. Climate change and amplified representations of natural hazards in institutional cultures Nat. Hazard Sci. 2019, 13, 354

52. Masud, M.M.; Azam, M.N.; Mohiuddin, M.; Banna, H.; Akhtar, R.; Alam, A.S.A.F.; Begum, H. Adaptation Barriers and Strategies towards Climate Change: Challenges in the Agricultural Sector. J. Clean. Prod. 2017, 156, 698-706. [CrossRef]

53. Coutts, A.; Beringer, J.; Tapper, N. Changing Urban Climate and CO2Emissions: Implications for the Development of Policies for Sustainable Cities. Urban Policy Res. 2010, 28, 27-47. [CrossRef]

54. Rowan, N.J.; Galanakis, C.M. Unlocking challenges and opportunities presented by COVID-19 pandemic for cross-cutting disruption in agri-food and green deal innovations: Quo Vadis? Sci. Total Environ. 2020, 748, 141362. [CrossRef]

55. Begum, H.; Alam, A.S.A.F.; Er, A.C.; Ghani, A.B.A. Environmental sustainability practices among palm oil millers. Clean Technol. Environ. Policy 2019, 21, 1979-1991. [CrossRef]

56. Ozili, P.K.; Arun, T. Spillover of COVID-19: Impact on the Global Economy. Available at SSRN 3562570. 2020. Available online: https://ideas.repec.org/p/pra/mprapa/99317.html (accessed on 14 March 2020).

57. Messner, W. The institutional and cultural context of cross-national variation in COVID-19 outbreaks. medRxiv 2020. [CrossRef]

58. Ruscio, B.A.; Brubaker, M.; Glasser, J.; Hueston, W.; Hennessy, T.W. One Health-A strategy for resilience in a changing arctic. Int. J. Circumpolar Health 2015, 74, 27913. [CrossRef]

59. Afelt, A.; Frutos, R.; Devaux, C. Bats, coronaviruses, and deforestation: Toward the emergence of novel infectious diseases? Front. Microbiol. 2018, 9, 702. [CrossRef] [PubMed]

60. Olivero, J.; Fa, J.E.; Real, R.; Márquez, A.L.; Farfán, M.A.; Vargas, J.M.; Gaveau, D.; Salim, M.A.; Park, D.; Suter, J.; et al. Recent loss of closed forests is associated with Ebola virus disease outbreaks. Sci. Rep. 2017, 7, 1-9. [CrossRef]

61. Godfray, H.C.J.; Aveyard, P.; Garnett, T.; Hall, J.W.; Key, T.J.; Lorimer, J.; Pierrehumbert, R.T.; Scarborough, P.; Springmann, M.; Jebb, S.A. Meat consumption, health, and the environment. Science 2018, 361, eaam5324. [CrossRef]

62. Food and Agriculture Organization (FAO). 2007. Available online: https://www.fao.org/newsroom/en/news /2007/1000660 /index.html (accessed on 12 April 2020).

63. Salata, C.; Calistri, A.; Parolin, C.; Palù, G. Coronaviruses: A paradigm of new emerging zoonotic diseases. Pathog. Dis. 2020, 77, ftaa006. [CrossRef] [PubMed] 
64. Reyes, R.; Ahn, R.; Thurber, K.; Burke, T.F. Urbanization and Infectious Diseases: General Principles, Historical Perspectives, and Contemporary Challenges. In Challenges in Infectious Diseases. Emerging Infectious Diseases of the 21st Century; Fong, I., Ed.; Springer: Berlin/Heidelberg, Germany, 2013; pp. 123-146, ISBN 978-1-4614-4496-1.

65. Honigsbaum, M. The Pandemic Century: One Hundred Years of Panic, Hysteria and Hubris; W. W. Norton \& Company: New York, NY, USA, 2020.

66. Lipsitch, M.; Swerdlow, D.L.; Finelli, L. Defining the epidemiology of Covid-19—Studies needed. N. Engl. J. Med. 2020, 382, 1194-1196. [CrossRef] [PubMed]

67. Fang, L.; Karakiulakis, G.; Roth, M. Are patients with hypertension and diabetes mellitus at increased risk for COVID-19 infection? Lancet Respir. Med. 2020, 8, e21. [CrossRef]

68. Giannis, D.; Ziogas, I.A.; Gianni, P. Coagulation disorders in coronavirus infected patients: COVID-19, SARS-CoV-1, MERS-CoV and lessons from the past. J. Clin. Virol. 2020, 127, 104362. [CrossRef]

69. Zheng, Y.Y.; Ma, Y.T.; Zhang, J.Y.; Xie, X. COVID-19 and the cardiovascular system. Nat. Rev. Cardiol. 2020, 17, 259-260. [CrossRef]

70. BBC News. Coronavirus: Pandemic Sends US Jobless Rate to $14.7 \%$. Available online: https://www.bbc.com/news/business-52 591262 (accessed on 8 May 2020).

71. Rediff Realtime News. Prices of Agricultural Commodities Drop 20\% Post COVID-19 Outbreak. Available online: https: / / realtime.rediff.com/news/india/Prices-of-agricultural-commodities-drop-20-post-COVID19outbreak/95507859 9584b749?src=interim_alsoreadimage (accessed on 20 March 2020).

72. Anderson, R.M.; Heesterbeek, H.; Klinkenberg, D.; Hollingsworth, T.D. How will country-based mitigation measures influence the course of the COVID-19 epidemic? Lancet 2020, 395, 931-934. [CrossRef]

73. Meo, S.A.; Al-Khlaiwi, T.; Usmani, A.M.; Meo, A.S.; Klonoff, D.C.; Hoang, T.D. Biological and epidemiological trends in the prevalence and mortality due to outbreaks of novel coronavirus COVID-19. J. King Saud Univ. Sci. 2020, 32, 2495-2499. [CrossRef]

74. British Plastics Federation (BPF). COVID-19: Guidance \& Legislation for the UK Plastics Industry. 2020. Available online: https:/ / www.bpf.co.uk/recomed.aspx. (accessed on 11 June 2021).

75. Chinazzi, M.; Davis, J.T.; Ajelli, M.; Gioannini, C.; Litvinova, M.; Merler, S.; Piontti, A.P.Y.; Mu, K.; Rossi, L.; Sun, K.; et al. The effect of travel restrictions on the spread of the 2019 novel coronavirus (COVID-19) outbreak. Science 2020, 368, 395-400. [CrossRef]

76. Bai, Y.; Yao, L.; Wei, T.; Tian, F.; Jin, D.Y.; Chen, L.; Wang, M. Presumed asymptomatic carrier transmission of COVID-19. JAMA 2020, 323, 1406-1407. [CrossRef]

77. Hemida, M.G.; Abduallah, M.M.B. The SARS-CoV-2 outbreak from a one health perspective. One Health 2020, 10, 100127. [CrossRef]

78. IMF. International Monetary Fund, World Economic Outlook, April 2021. Latest World Economic Outlook Growth Projections. Available online: https:/ /www.imf.org/en/Publications/WEO/Issues/2021/03/23/world-economic-outlook-april-2021 (accessed on 11 June 2021).

79. Zambrano-Monserrate, M.A.; Ruano, M.A.; Sanchez-Alcalde, L. Indirect effects of COVID-19 on the environment. Sci. Total Environ. 2020, 728, 138813.

80. Baldwin, R.; Tomiura, E. Thinking ahead about the trade impact of COVID-19. In Economics in the Time of COVID-19; CEPR Press, Centre for Economic Policy Research: London, UK, 2020; Volume 59.

81. Harapan, H.; Itoh, N.; Yufika, A.; Winardi, W.; Keam, S.; Te, H.; Megawati, D.; Hayati, Z.; Wagner, A.L.; Mudatsir, M. Coronavirus disease 2019 (COVID-19): A literature review. J. Infect. Public Health 2020, 13, 667-673. [CrossRef] [PubMed]

82. Ficetola, G.F.; Rubolini, D. Climate affects global patterns of COVID-19 early outbreak dynamics. medRxiv 2020. [CrossRef]

83. ESA. COVID-19: Nitrogen Dioxide over China. 2020. Available online: https://www.esa.int/Applications/Observing_the_ Earth/Copernicus/Sentinel-5P/COVID-19_nitrogen_dioxide_over_China (accessed on 4 April 2020).

84. ESA. 2020. Available online: https://www.esa.int/Applications/Observing_the_Earth/Copernicus/Sentinel-5P/Coronavirus_ lockdown_leading_to_drop_in_pollution_across_Europe (accessed on 4 April 2020).

85. Sharma, P.; Dhar, A. Effect of hydrogen supplementation on engine performance and emissions. Int. J. Hydrog. Energy 2018, 43, 7570-7580. [CrossRef]

86. McCloskey, B.; Heymann, D.L. SARS to novel coronavirus-old lessons and new lessons. Epidemiol. Infect. 2020, 148, e22. [CrossRef]

87. Lau, H.; Khosrawipour, V.; Kocbach, P.; Mikolajczyk, A.; Schubert, J.; Bania, J.; Khosrawipour, T. The positive impact of lockdown in Wuhan on containing the COVID-19 outbreak in China. J. Travel Med. 2020, 27, taaa037. [CrossRef]

88. American Veterinary Medical Association. COVID-19. Available online: https://www.avma.org/resources-tools/animal-healthand-welfare/covid-19 (accessed on 20 March 2020).

89. BASF Frets IndustryWeek COVID-19 Is Coming for the Chemical Industry in 2020. 2020. Available online: https: //www.industryweek.com/supply-chain/planningforecasting/article/21125045/covid19-is-coming-for-the-chemicalindustry-in-2020-basf-frets (accessed on 9 May 2020).

90. Reuters. OPEC's Pact with Russia Falls Apart, Sending Oil into Tailspin. Mar 6. 2020. Available online: https://www.reuters. com/article/us-opec-meeting-idUSKBN20T0Y2 (accessed on 23 March 2020).

91. The Guardian. MPs in Plea to Government over UK's Covid-19 Stockpiling. 2020. Available online: https://www.theguardian. com/world/2020/mar/21/mps-plea-government-uk-covid-19-stockpiling-coronavirus (accessed on 23 March 2020). 
92. Jack, S. BBC News; What Are Shops Doing about Stockpiling? 22 March 2020. Available online: https://www.bbc.com/news / business-51737030 (accessed on 23 March 2020).

93. Jack, S. BBC News; Online Shopping Website Ocado Suspends Service. 18 March 2020. Available online: https:/ /www.bbc.com/ news / business-5194198 (accessed on 23 March 2020).

94. BBC News. Stockpiling 'Will Hit Vulnerable', Food Bank Warns. 13 March 2020. Available online: https://www.bbc.com/news/ uk-england-beds-bucks-herts-51856592 (accessed on 23 March 2020).

95. BBC News. Food Bank Shortage Blamed on Coronavirus Panic. 13 March 2020. Available online: https://www.bbc.com/news / uk-england-london-51837892 (accessed on 23 March 2020).

96. Calma, J. 2020. Available online: https:/ /www.theverge.com/2020/3/26/21194647/the-covid-19-pandemic-is-generating-tonsof-medical-waste (accessed on 5 April 2020).

97. Varotto, A.; Spagnolli, A. Psychological strategies to promote household recycling. A systematic review with meta-analysis of validated field interventions. J. Environ. Psychol. 2017, 51, 168-188. [CrossRef]

98. Ma, B.; Li, X.; Jiang, Z.; Jiang, J. Recycle more, waste more? When recycling efforts increase resource consumption. J. Clean. Prod. 2019, 206, 870-877. [CrossRef]

99. Bir, B. Single-Use Items Not Safest Option Amid COVID-19. 2020. Available online: https://www.aa.com.tr/en/health/singleuse-items-not-safest-option-amidcovid-19/1787067 (accessed on 5 April 2020).

100. Rothan, H.A.; Byrareddy, S.N. The epidemiology and pathogenesis of coronavirus disease (COVID-19) outbreak. J. Autoimmun. 2020, 109, 102433. [CrossRef] 